\title{
THE EFFECT OF INTERVALS FROM SPERM WASH TO INTRA UTERINE INSEMINATION (IUI) TIME ON PREGNANCY RATE
}

\author{
Esra Bulgan KILICDAG
}

Department of Obstetrics and Gynecology, Baskent University Faculty of Medicine, Adana, Turkey

\begin{abstract}
SUMMARY
Background: The aim of our study was to assess the influence of intervals from sperm wash to intra uterine insemination on the IUI outcome.

Material and methods: This was prospective study of 1125 cycles in Obstetrics and Gynecology Department of Baskent University Medical Faculty between January 2011 and December 2011.

Results: In totally 1125 cycles IUI performed within < 30 minute in 202 cycle, 30-59 minute in 367 cycle, 60-89 minute in 381 cycle, 90-119 minute in 114 cycle, 120-180 minute in 61 cycle. Pregnacy rate was \%4.5,\%7.9,\%11,\%8.8, ve \%11.5 respectively. We reanalyzed $<30$ minutes and other groups again we found that the difference reached statically significant level (\%4.5 vs \%9.5)(p: 0.01). In good prognostic patients with total motile sperm count was $\geq 10 x 106$, pregnancy rates were lower in patients whose inseminated in $<30$ minute than the others $(\% 5.2$ vs \%10.1)(p:0.024).

Conclusion: The results of our study showed that if a washing sperm can be incubated minimum 30 minute at 37 C the pregnancy rate is optimum. The longer period up to 180 minute doesn't compromise the pregnancy rate.
\end{abstract}

Key words: IUI, pregnancy rates, sperm wash, timing

Journal of Turkish Society of Obstetrics and Gynecology, (J Turk Soc Obstet Gynecol), 2012; Vol: 9, Issue: 3, Pages: 159- 63

\section{SPERM HAZIRLIĞI İLE INTRAUTERIN INSSEMINASYON ARASI SÜRENIN GEBELIK ORANLARINA ETKISI}

\section{ÖZET}

\begin{abstract}
Amaç: Yaygın olarak kullanılan intrauterin inseminasyon (IUI) sikluslarında semen hazırlama ve IUI arasındaki sürenin IUI sonuçlarına etkisini prospektif olarak araştırmayı amaçladık.

Gereç ve yöntem: Ocak 2011- Aralı 2011 tarihleri arasında Başkent Üniversitesi Tıp Fakültesi Kadın Hastalıkları ve Doğum Bölümü, YÜT merkezinde IUI programına alınan 1125 siklus prospektif olarak değerlendirmeye alınmıştır. Bulgular: Çalışmaya alınan 1125 siklusun 202'sinde <30 dk, 367 'sinde 30-59 dk, 381'inde 60-89dk, 114'ünde 90-119dk, 61 'inde 120-180 dk içerisinde IUI uygulandiğl, bu gruplarda sirastyla gebelik oranlarının \%4.5,\% olduğu tespit edildi. Bu nedenle 30 dakikada yapllan IUI'lar ile diğer sikluslar toplam olarak tekrar analiz edildiğinde aradaki farkin istatistiksel olarak anlamlı düzeye eriştiği izlendi (\%4.5 vs \%9.5)(p: 0.01). IUI başarlsında önemli prediktörlerden biri olan insemine edilen total motil sperm sayısının 10 milyon üzerinde olduğu sikluslarda da gebelik oranları ilk 30 dakikada IUI yapılanlarda istatistiksel olarak anlamlı ölçüde düşük tespit edildi (\%5.2 vs \%10.1)(p: 0.024).

Yorum: Sperm hazırlandıktan sonra IUI sikluslarında spermin 37 C de en az yarım saat bekletilmesi optimum gebelik oranlarını sağlamakta ve 180 dakikaya kadar olan bekleme süreleri sonuçları olumsuz etkilememektedir.
\end{abstract}

Anahtar kelimeler: gebelik oranları, IUI, sperm yıkama, zamanlama

Türk Jinekoloji ve Obstetrik Derneği Dergisi, (J Turk Soc Obstet Gynecol), 2012; Cilt: 9, Sayl: 3, Sayfa: $159-63$

Address for Correspondence: Dr. Esra Bulgan Kılıçdağ. Gazipaşa mah. Baraj cad. no. 7 Seyhan, Adana Phon.: + 90 (532) 6735754

e-mail: ebkilicdag@hotmail.com

Received: 20 February 2012, revised: 19 March 2012, accepted: 20 March 2012, online publication: 22 March 2012 


\section{INTRODUCTION}

Intrauterine insemination (IUI), an assisted reproductive technique widely used all over the world, is a distinguished method which is cheaper and less invasive compared to other assisted reproductive techniques ${ }^{(1)}$. Intrauterine insemination is widely used in mildmedium male factor infertility, unexplained infertility, cervical factor and ovulatory problems ${ }^{(2)}$. Several factors, such as maternal age, cause of infertility, uterine factor, sperm parameters, presence of endometriosis, number of cycles and ovulation induction agents, have been investigated as prognostic factors for IUI success (3-7). However, there is limited number of studies on the effect of other parameters that may affect pregnancy rates with IUI, such as the effect of the place of semen collection (house, clinic), intervals from semen collection to sperm wash and intervals from sperm wash to IUI on the IUI outcomes ${ }^{(8-11)}$. In a retrospective study, it was reported that semen collection at home rather than in the clinic, increasing the interval between semen collection and sperm wash from 30 minutes to 60 minutes, and increasing the interval between sperm wash and IUI from 90 minutes to 120 minutes resulted in a significant decrease in pregnancy rate in hMGIUI cycles(11). On the other hand, it was found in another study that semen collection at home and delayed transport period did not have any effect on pregnancy rate $^{(10)}$. In our clinic, we ask semen collection to be performed in the clinic in all IUI cycles. Yet, duration between sperm wash and IUI may vary depending on many factors (how busy the clinic and andrology laboratory are, patient's arrival time, etc.)

In this prospective study, we aimed to assess the effect of intervals between sperm wash and IUI on the IUI outcomes.

\section{MATERIALS AND METHODS}

The cycles included in the IUI program in the Obstetrics and Gynecology Department of Başkent University Faculty of Medicine between January 2011 and December 2011 were assessed prospectively. Approval was received for this study from the Ethics Committee of Başkent University (Project no: KA10/166). The study included the first two cycles of patients for whom gonadotrophin-controlled ovarian hyperstimulation and IUI was planned for unexplained infertility or mild male factor. Patients with basal FSH values higher than $12 \mathrm{IU}$ and with endometrial thickness lower than $6 \mathrm{~mm}$ on the day of HCG administration were excluded from the study. On the day of intrauterine insemination, the intervals between semen collection and sperm wash, and between sperm wash and IUI were recorded carefully. While assessing the study results, the duration between sperm wash and IUI was evaluated in five groups with 30 minute intervals.

Basic tests for infertility research included sperm analysis after an abstinence of 3-7 days, hormonal analysis and pelvic ultrasonography on day 3 of menstrual cycle, histerosalpingography (HSG) between days 7-11 of menstrual cycle, and mid-luteal progesterone measurement for ovulation assessment between days 711. Based on the findings, patients were categorized as either mild-medium male factor or unexplained infertility groups. Ovulatory cases with normal HSG and without male factor, and cases who were diagnosed with oligoanovulation and who failed to achieve pregnancy despite at least 3 ovulatory cycles with ovulation induction were classified as "unexplained infertility". Cases with sperm count less than 20x106 (oligospermia), fast forward sperm percentage less than $25 \%$ and total percentage of slow forward moving sperm $(\mathrm{A}+\mathrm{B})$ less than $50 \%$ (asthenospemia) in motility assessment were evaluated as male factor. As per March 2010 SUT law, patients with sperm count over 5 million were included in the IUI program. Ovulation induction (OI) recombinant FSH preparations (Gonal-F, Serono \& Puregon, Organon, Turkey) were used. According to the protocol applied in our clinic, treatment with rFSH in OI was initiated with doses ranging from 50 to $150 \mathrm{IU}$ on day 3 or 4 of menstrual cycle, based on patients'weight, age and antral follicle count in USG. Monitorization was started on day 6 of the treatment. Monitorization intervals were determined according to follicle size. The presence of at least one follicle over $18 \mathrm{~mm}$ was taken as criterion to trigger ovulation. Cycle was cancelled in cases in which more than 2 follicles over $16 \mathrm{~mm}$ were detected in the follow-up. For this purpose, $10000 \mathrm{IU}$ hCG (Ovitrelle flk, Merck Serono, Pregnyl flk, MSD, Turkey) was used. On day 21 of menstrual cycle, ovulation and progesterone were measured and checked in all patients. Luteal phase support was not performed in any of the cycles. A single insemination was performed 36-40 hours after hCG was administered in all cycles. 
For sperm wash, $2 \mathrm{ml}$ was taken from $80 \%$ gradient medium (Suprasperm, Tek Medical Service, Denmark) by using a $1 \mathrm{ml}$ pipette (Falcon, 7521, Aksuvar and Assist Medical, USA) and slowly dropped into a conic tube (Falcon, 2095, Aksuvar and Assist Medical, USA). Then, $2 \mathrm{ml}$ was taken from $55 \%$ gradient medium (Suprasperm, Tek Medical Service, Denmark) and slowly dropped into the tube. The liquefied semen sample was slowly stirred and counted by the help of a $2 \mathrm{ml}$ pipette (Falcon, 7507, Aksuvar and Assist Medical, USA) and then slowly dropped on gradient medium and centrifuged at $300 \mathrm{~g}(1200 \mathrm{rpm})$ for 230 minutes. At the end of this period, supernatant part was taken and added on the 3 $\mathrm{ml}$ pellet from the Medi-cult IVF ( Tek Medical Service, Denmark) washing medium placed in a $15 \mathrm{ml}$ roundbottom tube (Falcon 2001, Aksuvar and Assist Medical, USA) on the pellet at the bottom and then resuspensed. Supernatant part was removed after centrifuge. Medicult IVF washing medium (Tek Medical Service, Denmark) was added to leave $0.6 \mathrm{ml}$ final volume on the pellet and then resuspensed. It was placed in a $5 \mathrm{ml}$ tube (Falcon 2003, Aksuvar and Assist Medical, USA) by using a $1 \mathrm{ml}$ pipette (Falcon 7521, Aksuvar and Assist Medical, USA) and allowed to stand in laminar flow after the final count was performed. All patients were asked to come to the clinic with a full bladder. After the vulva and vagina were washed with physiologic saline, the prepared sperm was injected slowly into intrauterine cavity, accompanied by transabdominal ultrasonography (USG), using artificial insemination catheter (Wallace(r), Smiths Medical International Ltd, UK), to reach a total volume of 0,5 $\mathrm{ml}$. The patient was allowed to rest for 10-15 minutes and then was told to return to normal daily activities. Patients was subjected to $\beta$-hCG test if they had not experienced a menstrual cycle in 14 days following the day of hCG. Patients with positive test results were called back to the clinic two weeks later for transvaginal USG. Patients whose pregnancy was confirmed with USG were accepted as pregnant in this study.

\section{Statistical method}

Results were given as mean \pm standard deviation. In order to analyze pregnancy rated in IUI cycles, chisquare test or Fisher's exact test, if necessary, were used. Pearson correlation test was used to assess the relationship between the variables and pregnancy. $\mathrm{P}<0.05$ was accepted to be significant.

\section{Results}

1125 cycles in total were analyzed. In the correlation analysis, there was no statistically significant difference between the groups in terms of age, infertility period, basal FSH, follicle count, and inseminated mean TMSS (total motil sperm count) among the parameters that affect pregnancy rates (Table I). The interval from sperm wash to IUI was examined in five groups, with 30 minute intervals, and it was found that the lowest pregnancy rates were in the cycles performed in the first 30 minutes (Table II). Thus, the IUIs performed in 30 minutes and other cycles were re-analyzed, and this difference was observed to have reached to a statistically significant level (Table III) (p:0.01). When we re-analyzed the data in inseminated cycles with more than 10 million sperm count in total, we found that pregnancy rates decreased in cycles in which IUI was administered in the first 30 minutes and this decrease was statistically significant (Table IV).

Table I: Demographic data.

\begin{tabular}{llllll}
\hline & \multicolumn{5}{c}{ Interval between sperm wash and IUI (minute) } \\
& $\mathbf{1 2 0 - 1 8 0}$ & $\mathbf{9 0 - 1 1 9}$ & $\mathbf{6 0 - 8 9}$ & $\mathbf{3 0 - 5 9}$ & $<\mathbf{3 0}$ \\
\hline Woman's age & $29.1 \pm 4.4$ & $28.8 \pm 5.3$ & $29.3 \pm 4.5$ & $29.2 \pm 4.6$ & $29.3 \pm 5.1$ \\
Infertility period & $4.6 \pm 3.6$ & $4.2 \pm 2.8$ & $4.6 \pm 3.3$ & $4.5 \pm 3.1$ & $4.5 \pm 3.5$ \\
Basal FSH & $5.5 \pm 1.7$ & $5.6 \pm 2.1$ & $5.5 \pm 1.1$ & $5.5 \pm 1.9$ & $5.4 \pm 1.7$ \\
Inseminated & & & & & \\
TMSS & $37.4 \pm 23.7$ & $35.5 \pm 23.9$ & $32.8 \pm 24.3$ & $31.8 \pm 24.3$ & $25.8 \pm 19.8$ \\
Follicle count & $1.6 \pm 0.6$ & $1.7 \pm 0.8$ & $1.6 \pm 07$ & $1.5 \pm 0.7$ & $1.7 \pm 0.9$ \\
\hline TMSS (total motil sperm count) &
\end{tabular}

Table II: Interval between sperm wash and IUI and pregnancy rates.

\begin{tabular}{llllll}
\hline \multicolumn{7}{c}{ Interval between sperm wash and IUI (minute) } \\
& $\mathbf{1 2 0 - 1 8 0}$ & $\mathbf{9 0 - 1 1 9}$ & $\mathbf{6 0 - 8 9}$ & $\mathbf{3 0 - 5 9}$ & $<\mathbf{3 0}$ \\
\hline Number of cycles & & & & & \\
$(1125)$ & 61 & 114 & 381 & 367 & 202 \\
Pregnancy rates & 7 & 10 & 42 & 29 & 9 \\
& $(\% 11.5)$ & $(\% 8.8)$ & $(\% 11)$ & $(\% 7.9)$ & $(\% 4.5)$ \\
\hline
\end{tabular}

Table III: Negative effect of $>30$ minute interval between sperm wash and IUI on pregnancy rates.

\begin{tabular}{llll}
\hline & $\begin{array}{l}\text { Interval between sperm wash } \\
\text { and IUI (minute) }\end{array}$ & $\mathbf{p}$ \\
& $\geq \mathbf{3 0}$ & $<\mathbf{3 0}$ & \\
\hline $\mathrm{N}(1125)$ & 923 & 202 & \\
Pregnancy rates & $88(\% 9.5)$ & $9(\% 4.5)$ & 0.01 \\
\hline
\end{tabular}


Table IV: Effect of the interval between sperm wash and IUI on pregnancy rates in cycles with TMSS $>10$ million after sperm wash.

\begin{tabular}{llll}
\hline & \multicolumn{2}{l}{$\begin{array}{l}\text { Interval between sperm wash } \\
\text { and IUI (minute) }\end{array}$} & $\mathbf{p}$ \\
& $\geq \mathbf{3 0}$ & $<\mathbf{3 0}$ & \\
\hline $\mathrm{N}(988)$ & 814 & 174 & \\
Pregnancy rates & $82(\% 10.1)$ & $9(\% 5.2)$ & 0.024 \\
\hline
\end{tabular}

\section{DISCUSSION}

The objective of our prospective study was to find the optimal time between sperm wash and insemination in intrauterine insemination cycles. Contrary to the general view, we have demonstrated that having an interval of at least 30 minutes, rather than initiating IUI immediately after sperm wash, increases success rate in IUI cycles.

In our literature review, in a single retrospective study conducted with 102 patients to determine the effect of the interval between sperm wash and IUI on pregnancy rates, it was reported that there was no difference between performing IUI in intervals of 30 minutes and 31-60 minutes, but pregnancy rates were higher in these two groups compared to the group in which IUI was administered after 60 minutes, and that no pregnancy was observed in the group in which hMG was used after 180 minutes ${ }^{(11)}$. In this study, in the groups with 30 minutes, 31-60 minutes, $>60$ minutes interval, pregnancy rates were $6 \%, 6 \%$ and $15 \%$, respectively, in the CC group; and $67 \%, 42 \%$ and $7 \%$, respectively, in the hMG group. It is striking that in our study pregnancy rates were also lower in IUIs performed in the first 60 minutes in the CC group. In addition, high pregnancy rates in cycles with $\mathrm{hMG}$ were also noteworthy. In a study conducted by Rannall GW et al., it was reported that pregnancy rates were not affected in gonadotropine-administred cycles by the two-hour duration before the sample was brought to the clinic after sperm wash was performed following sperm collection at home ${ }^{(10)}$. In our study, as we aimed to determine the effect of the waiting period after sperm wash on pregnancy rates, all samples were collected in the clinic and sperm wash procedure was initiated immediately after the ejaculate was liquefied. Since ovulation induction with gonadotropines and IUI are required to prepare IVF report for patients in line with the new SUT law, ovulation induction with gonadotropines was performed in all cycles. Owing to this design of the study, we had the opportunity to assess the effect of the interval after sperm wash by eliminating additional factors such as the effect of ovulation induction agents, transfer of sperm from home to the clinic.

In the correlation analysis we performed for parameters that could affect pregnancy rates in intrauterine insemination cycles, we found that age, infertility period, basal FSH, follicle count, TMSS (total motil sperm count) in inseminated medium, and waiting period of the inseminate were effective. There was no statistically significant difference between the groups in terms of age, infertility period, basal FSH, follicle count, inseminated mean TSS. However, when the intervals between sperm wash and IUI were examined, it was striking that the lowest pregnancy rates were observed in the cycles performed in the first 30 minutes.

Our aim in using sperm preparation techniques was to distinguish normal sperms in terms of motility and morphology, and to increase sperm capacitation and, thus, pregnancy rates by removing prostaglandin, dead sperms and infectious agents ${ }^{(13)}$. If we consider that sperms separated from the seminal plasma and liquid preserved their motility and viability for longer periods compared to unprocessed ones, and that sperms, which could not be capacitated when incubated in room temperature, achieved capacitation by incubation at $37^{\circ} \mathrm{C}$ (14); our higher pregnancy rates obtained with sperms which were allowed to stand at $37^{\circ} \mathrm{C}$ for an interval longer than 30 minutes can be explained by the interval long enough to enable the capacitation of sperms. After in vivo sperm capacitation, hyperactive motility and acrosome reaction develops in the sperm by stimuli such as human zona pellucida, progesterone or follicle liquid. Capacitation and acrosome reaction may develop in vitro when suitable conditions are provided. There are animal and human studies demonstrating that incubation temperature is a modulator in capacitation and acrosome reaction ${ }^{(15,16)}$. In a study which investigated the effect of sperm incubation at $37^{\circ} \mathrm{C}$ and room temperature, progressive sperm rates were similar in both groups, but those kept in room temperature did not show any hyperactive movement when examined in CASA system ${ }^{(16)}$.

Another reason for the higher pregnancy rate in the group with longer interval before IUI may be the increased possibility that insemination occurred after 
ovulation. Because, in a recent study, pregnancy rates were reported to be higher in IUIs performed after ovulation was detected by USG on the day of insemination ${ }^{(12)}$. Consequently, we demonstrated in our study that the interval of at least 30 minutes at $37^{\circ} \mathrm{C}$ was optimal in IUI cycles, and intervals up to 180 minutes did not affect the outcomes negatively.

\section{REFERENCES}

1. Kossakowski J, Stephenson M, Smith H Intrauterine insemination with husband's sperm: comparison of pregnancy rates in couples with cervical factor, male factor, immunological factor and diopathic infertility. Aust N Z J Obstet Gynaecol. 1993; 33(2): 183- 6 .

2. Ibérico G, Vioque J, Ariza N, Lozano JM, Roca M, Llácer J, et al. Analysis of factors influencing pregnancy rates in homologous intrauterine insemination. Fertil Steril 2004; 81: 1308- 13 .

3. Sinikka NH, Candido T, Risto B, Leena T, Hannu M. Intrauterine insemination treatment in subfertility: an analysis of factors affecting outcome. Hum Reprod 1999; 14: 698703.

4. Awonuga A, Govindbhai J. Is waiting for endogenous luteinizing hormone surge and/or administration of human chorionic gonadotrophin of benefit in intrauterine insemination? Hum Reprod 1999; 14: 765- 70.

5. Gezginç K, Görkemli H, Celik C, Karatayli R, Ciçek MN, Olakoglu MC. Comparison of single versus double intrauterine insemination. Taiwan J Obstet Gynecol 2008; 7: 57- 61.

6. Demirol A, Gurgan T. Comparison of different gonadotrophin preparations in intrauterine insemination cycles for the treatment of unexplained infertility: a prospective, randomized study. Hum Reprod 2007; 22: 97- 100.

7. Freour T, Jean M, Mirallie S, Langlois ML, Dubourdieu S,
Barriere P. Predictive value of CASA parameters in IUI with frozen donor sperm. Int J Androl. 2008.

8. Gyun Jee Song Ph.D., Rita Herko B.S. And Vivian Lewis M.D. Location of semen collection and time interval from collection to use for intrauterine insemination. Fertil Steril 2007 Dec; 88(6): 1689- 91.

9. Alexander CJ, King J, Lipari C, Zhao Y and Wallach EE. Does the Time Interval between Semen Collection, Processing and Intrauterine Insemination affect results of IUI. J Obstet Gynecol India. 2009; 59(5): 407- 9.

10. Randall GW, Gantt PA. Intrauterine insemination results in couples requiring extended semen transport time. Int J Fertil Womens Med. 2007; 52(1): 28- 34.

11. Yavas Y, Selub MR. Intrauterine insemination (IUI) pregnancy outcome is enhanced by shorter intervals from semen collection to sperm wash, from sperm wash to IUI time, and from semen collection to IUI time. Fertil Steril. 2004; 82(6): 1638- 47.

12. Akanji Tijani H, Bhattacharya S. The role of intrauterine insemination in male infertility. Hum Fertil (Camb). 2010; 13(4): 226- 32.

13. Ghanem ME, Bakre NI, Emam MA, Al Boghdady LA, Helal AS, Elmetwally AG, Hassan M, Albahlol IA, Elzayat MM. The effects of timing of intrauterine insemination in relation to ovulation and the number of inseminations on cycle pregnancy rate in common infertility etiologies. Hum Reprod 2011 Mar; 26(3): 576- 83.

14. Petrella C, Hsieh J, Thrift K, Jarow JP, Zacur H, Zhao Y. Optimizing incubation conditions for the preservation of sperm motility in processed semen samples. Fertil Steril. 2005; 84(2): 513- 5.

15. Si Y. Temperature-dependent hyperactivated movement of hamster spermatozoa. Biol Reprod. 1997 Dec; 57(6): 1407- 12.

16. Marín-Briggiler CI, Tezón JG, Miranda PV, Vazquez-Levin MH. Effect of incubating human sperm at room temperature on capacitation-related events. Fertil Steril. 2002 Feb; 77(2): 252- 9 . 